\title{
Construction of "Five-stage" Large Curriculum System for the Integration of Innovation and Learning Based on Cultivation of Professional Core Competence*
}

\author{
Mingbiao $\mathrm{Xu}^{1}$ \\ Yiwu Industrial \& Commercial \\ College
}

\author{
Dehong Peng ${ }^{2}$ \\ Yiwu Industrial \& Commercial \\ College
}

\begin{abstract}
It is of great significance for the teaching reform of constructional engineering major to construct a large curriculum system based on ability. Taking the house building as an example, this study programs the building process into "four work fields" through the task decomposition, carefully selects the contents of teaching, optimizes the setting of teaching methods, updates and improves the evaluation mode, and innovates and drives teaching. By optimizing and reorganizing the traditional for integration of innovation and learning based on the cultivation of professional core competence has been constructed, realizing the seamless connection between school and enterprise with "graduation-employment-entrepreneurship" through train.
\end{abstract}

\section{Keywords}

Professional Core Competence • Five-Stage • Integration of Innovation and Learning - Large Curriculum System

\footnotetext{
* Fund Project: Scientific research project of Zhejiang provincial department of education in 2015 (item No.: Y201534814); Teaching reform project of Yiwu Industrial \& Commercial College in 2016(Project No.: 2016jg05); Teaching reform project of Yiwu Industrial \& Commercial College in 2018(Project No.: 2018jg18)

${ }^{1}$ Correspondence to: Yiwu Industrial \& Commercial College, Yiwu, 322000, China. Email: 181607887@qq.com

${ }^{2}$ Yiwu Industrial \& Commercial College, Yiwu, 322000, China. Email: xmb305@126.com
}

Citation: Xu, M. B., \& Peng, D. H, Construction of "Five-stage" Large Curriculum System for the Integration of Innovation and Learning Based on Cultivation of Professional Core Competence. Educational Sciences: Theory \& Practice, 18(5), 2187-2194. http://dx.doi.org/10.12738/estp.2018.5.118 
Professional education must be enterprise-oriented, practice-oriented and student-oriented, innovate the curriculum system according to the regional economic development, reform the teaching methods, optimize the teaching process, and construct the large curriculum for integration of innovation and learning based on the professional core competence so as to train more professionals needed by enterprises and create greater economic and social benefits.

The constructional engineering major is the core major of construction category with the seven major construction personnel and the second-level constructors as the post objectives, and trains more high-quality technical professionals with "understanding management, being able to construct and being good at starting up business".

\section{Construction Path of Large Curriculum System}

We should abandon the traditional three-stage teaching method of "public course, basic course, platform course", break the "teacher-based and material-based" closed-type teaching mode, change captive breeding into free breeding, adopt the omni bearing open teaching method, and determine professional orientation through the investigation and analysis of post vocational ability (Xu, 2016; Liu and Li, 2014; Liao, 2014). Through the analysis of learning situation, we can master students' knowledge reserve and receptivity. Besides, we should comprehensively consider the teaching environment and practice conditions, as well as construct "four work fields" based on the building process flow of a house. Through the analysis of vocational ability of each post, the contents of teaching are carefully selected and the teaching method is carefully designed so that the professional teaching is guided by innovation.

On the basis of careful study of the five-stage integration of innovation and learning of "initial learning of technology-professional introduction-skilled application-comprehensive expansion-innovation guidance" combined with the growth stage of various vocational posts, the actual situation of different basic abilities and general abilities is required. During the school period, we should cultivate the first three professional abilities and lay a solid foundation for the last two stages of "comprehensive expansion-innovation guidance". According to the cognitive law from the free man to the professional person, the top-level design is carried out and the large curriculum system for integration of innovation and learning is constructed, and the seamless connection between school and enterprise is established. Figure 1 is construction path of large curriculum system for integration of innovation and learning.

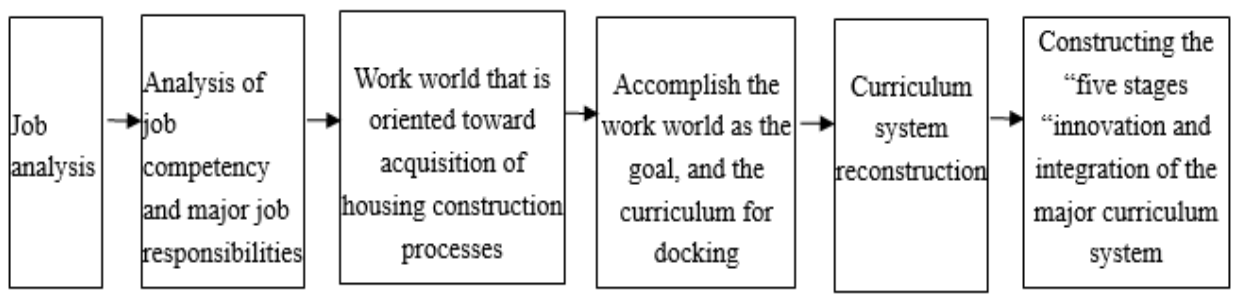

Figure 1. Construction path of large curriculum system for integration of innovation and learning 


\section{Measures for Construction of Large Curriculum System}

\section{Cultivation of professional core competence}

What is the core competence of constructional engineering students? Taking the house building as an example, this study programs the building process into "four work fields" through the task decomposition, as shown in Figure 2.

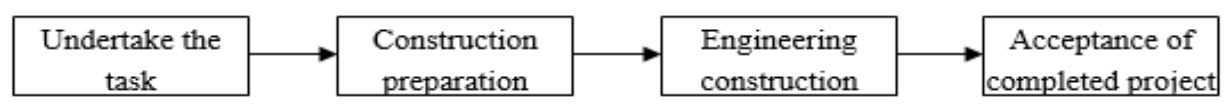

Figure 2. "Four work fields" of house building process

The core of "four work fields" is based on actual engineering task and the construction process, and integrates professional post standards into teaching content, realizing the connection of theoretical knowledge, technical skills, comprehensive expansion and post standards. The existing curriculum shall be optimized and reconstructed, and four modules will be innovated, including architectural recognition graph, constructional engineering construction technology, constructional engineering measurement and valuation and constructional engineering construction management to construct a large curriculum system for integration of innovation and learning.

\section{Selection and optimization of teaching contents}

When selecting the teaching contents, it is necessary to introduce new technology, new process, new equipment, new materials and new methods into the classroom according to the technical reality and the needs of the enterprise. At the same time, according to the engineering practice, the contents of course are carefully selected. Some obsolete knowledge points and teaching contents are deleted and cross information knowledge is added. In the construction of a large curriculum system, importance shall be attached to cultivation of quality, and the selection of basic theory is based on the principle of sufficiency while the selection of professional technology is based on the requirement of professional post. Public courses, such as advanced mathematics, college English, computer basic course shall be appropriately reduced. The professional courses should fully embody the specialty and practicality, and lay a good foundation for cultivating students' double-creative ability (innovation and start-up).

Skill teaching is the most important part of the curriculum system, which plays an important role in the process of cultivating the basic professional accomplishment and technical ability of the students majoring in architecture. The practice teaching should take the project teaching as the main line, set contents according to the skill module and melt the professional post standard in it so that the theoretical knowledge, professional skill and post standards are integrated deeply. Theory and practice are combined, extending the classroom to the construction site. 


\section{Implementation of diversified teaching method}

We shall abandon the traditional teaching method and adopt modern teaching method so that students can learn in practice, practice in learning and think in practice. Teachers are encouraged to widely adopt diversified teaching methods, such as case teaching, project teaching, heuristic teaching. Internet technology and cloud technology are widely adopted and open teaching is carried out so as to train students' ability to practice, to stimulate students' enthusiasm for professional learning, and to cultivate students' ability to discover and solve problems independently (Wu, 2015).

The course of constructional engineering major is characterized by many charts, many formulas and many symbols. Image technology and media technology must be widely used to make dynamic materials and media courseware. The combination of virtuality and reality is used to build study workshop for students to place students in the construction site situation, and teaching is finished in the project conception, design and implementation (Jiang, 2012).

The constructional engineering technology is made to go out of the classroom and root in the fertile soil of the construction site. Relying on the industry enterprises and taking the real project as the carrier, we will go deep into the construction line, cultivate the double-creative ability, and bring up more skilled talents.

\section{Reform of evaluation mode of curriculum}

We should change the evaluation mode based on the final examination thoroughly and explore a new way to evaluate the effect. By adopting the evaluation mechanism of "combination of formation and finality", the weight of evaluation can be enhanced. The use of digital evaluation standard can improve the accuracy of evaluation. In order to test students' ability to solve practical problems, a combination of multi evaluation methods, such as on-site operation and scheme innovation design, is used for the courses with higher training requirements.

For courses involving professional core competence and higher practical requirements such as "Constructional Engineering Survey”, “Architectural Recognition Graph and Construction”, "Main Structure Construction" and "Constructional Engineering Measurement and Valuation", outside-school experts and enterprise expert can be invited to participate in the evaluation, implementing the curriculum -certificate combination, namely the evaluation method combining professional qualification certificate and curriculum. The "separation of teaching and examination, third-party evaluation" evaluation mode shall be gradually adopted to promote the improvement of quality of teaching greatly (Zhang, 2013).

\section{Cultivation of educational idea of the integration of innovation and learning}

"Mass entrepreneurship and mass innovation" is not only a slogan but an action. College entrepreneurship is divided into e-commerce entrepreneurship and professional entrepreneurship. In-school students mainly engage in e-commerce entrepreneurship. Students are encouraged to engage in e-commerce entrepreneurship to foster entrepreneurship ideas and accumulate business experience so as to lay good foundation for a better 
professional start-up after graduation. Therefore, we should cultivate the consciousness of entrepreneurship and innovation of students majoring in architecture from multi-dimension and all-round way. To this end, we have designed two kinds of evaluation systems:

\section{Perfecting evaluation system of entrepreneurship}

Teachers are encouraged to guide entrepreneurship at the institutional level. At the beginning of each semester, the entrepreneurial evaluation task is issued, and the professional entrepreneurial rate is included in the teacher's teaching performance assessment. Teachers who have made outstanding achievements in guiding entrepreneurship will be given material and spiritual rewards, such as priority of promotion and title, and increase in bonus coefficient. Teachers with poor performance in entrepreneurship guidance should be punished. For example, teachers with the lowest rate of entrepreneurship among parallel classes in each grade should have "downgrades".

\section{Perfecting the incentive policy for entrepreneurship}

Students will be given a hand to start a business from the institutional level. Firstly, a flexible system of leave that is conducive to students' participation in start-up shall be established. During students' entrepreneurship conflicts with classroom learning, the students' management department and teachers should provide convenience according to the actual conditions of students' entrepreneurship. Secondly, the curriculum substitution system is conducted to replace the credit of the curriculum with the actual effect of starting a business. Students who start a business will be given a certain curriculum substitution at the beginning of each semester so as to reduce the pressure of practice of starting a business and professional study. Thirdly, special study and examination policy are implemented for students who start a business, which can help them to complete their studies by means of making up classes on holidays, individual tutoring and classified examinations. Fourth, a multi-evaluation system is carried out to break the unique theory of academic achievement and add the entrepreneurial performance evaluation, integrating the entrepreneurial performance into the party member development and award appraisal (Peng and $\mathrm{Xu}, 2012$ ).

\section{"Five-stage" Large Curriculum System for Integration of Innovation and Learning}

\section{Interface between "four work fields" and curriculum}

In order to achieve the above objectives of "four work fields", the course reconstruction is carried out by analyzing the occupational work nature and post ability requirements. The "four work fields" are interfaced with the course indicators, as shown in Table 1.

According to the characteristic of construction industry, and the development law from student to project manager, the practice of emphasizing learning theory and neglecting engineering practice is changed and great importance is attached to the cultivation of students' technical skills and practical ability. The traditional three- 
stage courses (public course, basic course, skill course) are optimized and reconstructed, and the five-stage curriculum system based on the construction process is constructed, as shown in Table 2. The five-stage curriculum system for integration of innovation and learning based on professional core competence is continuously reformed and improved in the teaching practice, realizing the seamless connection between school and enterprise with "graduation-employment -entrepreneurship" through train.

Table 1

Analysis of Interface of "Four Work Fields" with Course

\begin{tabular}{|c|c|c|c|}
\hline Work fields & Main duties and responsibilities & Post ability & Curriculum setting \\
\hline $\begin{array}{l}\text { Task } \\
\text { undertaking }\end{array}$ & $\begin{array}{l}\text { 1. Preparation of bidding documents and } \\
\text { tendering documents; } \\
2 \text {. Being familiar with the core contents } \\
\text { and construction laws and regulations of } \\
\text { various contracts; } \\
\text { 3. Technical and economic comparison } \\
\text { of programs }\end{array}$ & $\begin{array}{l}\text { Bidding and contract } \\
\text { management }\end{array}$ & $\begin{array}{l}\text { Constructional engineering } \\
\text { laws and regulations } \\
\text { Constructional engineering } \\
\text { economy } \\
\text { Project bidding and contract } \\
\text { management }\end{array}$ \\
\hline $\begin{array}{l}\text { Preparation of } \\
\text { construction }\end{array}$ & $\begin{array}{l}\text { 1. Participating in planning and } \\
\text { organization management in } \\
\text { construction; } \\
\text { 2. Participating in joint review of } \\
\text { drawings and technical disclosure; } \\
\text { 3. Participating in on-site organization } \\
\text { and coordination and implementing the } \\
\text { operation plan }\end{array}$ & $\begin{array}{l}\text { Organization and planning for } \\
\text { construction }\end{array}$ & $\begin{array}{l}\text { Architectural recognition } \\
\text { graph and construction } \\
\text { Building CAD } \\
\text { Organization design of } \\
\text { building construction }\end{array}$ \\
\hline $\begin{array}{l}\text { Engineering } \\
\text { construction }\end{array}$ & $\begin{array}{l}\text { 1. Being responsible for measuring and } \\
\text { setting out; } \\
\text { 2. Participating in the development of } \\
\text { progress plans and resource requirements } \\
\text { plans; } \\
\text { 3. Participating in cost control and } \\
\text { accounting; } \\
\text { 4. Participating in the establishment of a } \\
\text { safety management system for safety } \\
\text { management; } \\
\text { 5. Participating in the development of } \\
\text { quality control measures; } \\
\text { 6. Participating in contract management } \\
\text { and construction data arrangement }\end{array}$ & $\begin{array}{l}\text { Construction "three control, } \\
\text { three management and one } \\
\text { coordination" }\end{array}$ & $\begin{array}{l}\text { Architectural mechanics and } \\
\text { structure } \\
\text { Building materials and } \\
\text { testing } \\
\text { Building engineering survey } \\
\text { Foundation engineering } \\
\text { construction } \\
\text { Construction of main } \\
\text { structure engineering } \\
\text { Construction of waterproof } \\
\text { and decorative engineering } \\
\text { Construction management of } \\
\text { constructional engineering } \\
\text { Constructional engineering } \\
\text { measurement and valuation } \\
\end{array}$ \\
\hline $\begin{array}{l}\text { Completion } \\
\text { acceptance }\end{array}$ & $\begin{array}{l}\text { 1. Being responsible for acceptance of } \\
\text { inspection batch and sub-item project } \\
\text { quality; } \\
\text { 2. Participating in the project quality } \\
\text { acceptance of the division and unit; } \\
\text { 3. Being responsible for quality accident } \\
\text { treatment of construction project; } \\
\text { 4. Participating in the treatment of } \\
\text { construction quality defects; } \\
\text { 5. Being responsible for collection, } \\
\text { collation, roll-up and handover of } \\
\text { construction data }\end{array}$ & $\begin{array}{l}\text { Quality acceptance } \\
\text { Problem handling } \\
\text { Data arrangement } \\
\text { handover and filing }\end{array}$ & $\begin{array}{l}\text { Quality and safety } \\
\text { management of } \\
\text { constructional engineering } \\
\text { Management of } \\
\text { constructional engineering } \\
\text { materials }\end{array}$ \\
\hline
\end{tabular}

Among them, Courses 12, 20 and 23 constitute the pre-examination training module of the second-level constructor, which completely adopts the national second-level constructor examination teaching materials and the combination of courses and certificates, pays attention to the special strengthening training, and organizes some students to take the examination of second-level constructor. Courses 4, 24, 25, 28 constitute the professional entrepreneurship innovation training module from entrepreneurship awareness training, entrepreneurial knowledge accumulation, entrepreneurial behavior implementation to entrepreneurial ability promotion step by step. Other courses constitute the core competence training module of the constructional engineering technical specialty. 


\section{Construction of large curriculum system for integration of innovation and learning}

Table 2

"Five-stage" Large curriculum System for Integration of Innovation and Learning Based on Construction Process

\begin{tabular}{|c|c|c|c|}
\hline Five stages & Curriculum name & Core competence & $\begin{array}{c}\text { Combination of innovation } \\
\text { and learning }\end{array}$ \\
\hline \multirow{5}{*}{$\begin{array}{l}\text { General ability cultivating } \\
\text { stage }\end{array}$} & $\begin{array}{l}\text { Course 1: Military Training (including } \\
\text { education from the beginning) }\end{array}$ & & \multirow{5}{*}{$\begin{array}{l}\text { Basic learning, } \\
\text { attempt in e-commerce start- } \\
\text { up }\end{array}$} \\
\hline & Course 2: Ideological and Legal Basis & & \\
\hline & $\begin{array}{l}\text { Course 3: Foundation of Computer } \\
\text { Applications }\end{array}$ & & \\
\hline & $\begin{array}{l}\text { Course 4: Planning and Design for } \\
\text { Career (Entrepreneurship) }\end{array}$ & & \\
\hline & Course 5: PE & & \\
\hline \multirow{8}{*}{$\begin{array}{l}\text { Basic professional ability } \\
\text { cultivating stage }\end{array}$} & $\begin{array}{l}\text { Course 6: Architectural Recognition } \\
\text { Graph and Construction }\end{array}$ & \multirow{8}{*}{$\begin{array}{l}\text { Reading ability of } \\
\text { construction drawings } \\
\text { Engineering } \\
\text { measurement ability }\end{array}$} & \multirow{8}{*}{$\begin{array}{l}\text { Professional learning } \\
\text { E-commerce entrepreneurship }\end{array}$} \\
\hline & Course 7: Awareness Practice & & \\
\hline & Course 8: Construction CAD & & \\
\hline & $\begin{array}{l}\text { Course 9: Building Mechanics and } \\
\text { Structure }\end{array}$ & & \\
\hline & $\begin{array}{l}\text { Course 10: Building Materials and } \\
\text { Testing }\end{array}$ & & \\
\hline & $\begin{array}{l}\text { Course 11: Building Engineering } \\
\text { Survey }\end{array}$ & & \\
\hline & $\begin{array}{l}\text { Course 12: Constructional } \\
\text { Engineering Laws and Regulations }\end{array}$ & & \\
\hline & $\begin{array}{l}\text { Course 13: Constructional } \\
\text { Engineering Economy }\end{array}$ & & \\
\hline \multirow{9}{*}{$\begin{array}{l}\text { Professional core } \\
\text { competence cultivating } \\
\text { stage }\end{array}$} & $\begin{array}{l}\text { Course 14: Foundation Engineering } \\
\text { Construction }\end{array}$ & \multirow{4}{*}{$\begin{array}{l}\text { Engineering } \\
\text { construction ability }\end{array}$} & \multirow{9}{*}{$\begin{array}{l}\text { Professional learning } \\
\text { Seven major personnel E- } \\
\text { commerce entrepreneurships }\end{array}$} \\
\hline & $\begin{array}{l}\text { Course 15: Construction of Main } \\
\text { Structure Engineering }\end{array}$ & & \\
\hline & $\begin{array}{l}\text { Course 16: Construction of } \\
\text { Waterproof and Decorative } \\
\text { Engineering }\end{array}$ & & \\
\hline & $\begin{array}{l}\text { Course 17: Organization Design of } \\
\text { Building Construction }\end{array}$ & & \\
\hline & $\begin{array}{l}\text { Course 18: Constructional engineering } \\
\text { Measurement and Valuation }\end{array}$ & $\begin{array}{l}\text { Measurement and } \\
\text { valuation ability }\end{array}$ & \\
\hline & $\begin{array}{l}\text { Course 19: Project Bidding and } \\
\text { Contract Management }\end{array}$ & \multirow{4}{*}{$\begin{array}{l}\text { Engineering } \\
\text { management } \\
\text { capability }\end{array}$} & \\
\hline & $\begin{array}{l}\text { Course 20: Construction Management } \\
\text { of Constructional Engineering }\end{array}$ & & \\
\hline & $\begin{array}{l}\text { Course 21: Quality and Safety } \\
\text { Management of Constructional } \\
\text { Engineering }\end{array}$ & & \\
\hline & $\begin{array}{l}\text { Course 22: Management of } \\
\text { Constructional Engineering Materials }\end{array}$ & & \\
\hline \multirow{4}{*}{$\begin{array}{l}\text { Professional ability } \\
\text { improvement stage }\end{array}$} & $\begin{array}{l}\text { Course 23: Management and Practice } \\
\text { of Constructional Engineering }\end{array}$ & & \multirow{4}{*}{$\begin{array}{l}\text { Internship } \\
\text { Take an examination of the } \\
\text { second-level constructor } \\
\text { Professional entrepreneurship } \\
\text { attempt }\end{array}$} \\
\hline & $\begin{array}{l}\text { Course 24: Analysis of Professional } \\
\text { Entrepreneurship System }\end{array}$ & & \\
\hline & $\begin{array}{l}\text { Course 25: Company Registration } \\
\text { Process and Practice }\end{array}$ & & \\
\hline & Course 26: On-the-job Internship & & \\
\hline \multirow{2}{*}{$\begin{array}{l}\text { Comprehensive ability } \\
\text { improvement stage }\end{array}$} & Course 27: Graduation Internship & & \multirow{2}{*}{$\begin{array}{l}\text { Employment } \\
\text { Professional entrepreneurship }\end{array}$} \\
\hline & $\begin{array}{l}\text { Course 28: Business Management and } \\
\text { Operational Practice }\end{array}$ & & \\
\hline
\end{tabular}

\section{Conclusion}

The construction of large curriculum system is a systematic project, which needs to consider all kinds of related factors, analyze the relevant contents of curriculum reform. Top-level design reform ideas, key nodes, implementation steps are required to implement specific contents. 
Xu, Peng / Construction of "Five-stage" Large Curriculum System for the Integration of Innovation and Learning ...

The construction of the large curriculum system subverts the traditional mode of thinking, which is studentoriented and ability-based. It integrates school and enterprise and combines the theory and practice, which will bring more impetus to the teaching reform of the constructional engineering major and will produce extensive economic benefit and far-reaching social influence.

\section{References}

Xu, Z. Q. (2014). Construction of vocational ability training system for construction engineering technology specialty. Education and Occupation, (9), 80-84. http://dx.doi.org/10.13615/j.cnki.1004-3985.2006.24.006

Liu, X. P., \& Li, G. (2014). Building a competency-based training program and curriculum system for construction engineering professionals. China Construction Education, (11), 35-37.

Liao, K. B. (2014). Discussions on the curriculum reform of construction engineering technology specialty in higher vocational colleges. China Electric Power Education, (9): 116-117. http://dx.doi.org/10.19429/j.cnki.cn11-3776/g4.2009.18.054

$\mathrm{Wu}, \mathrm{M}$. Q. (2015). Construction of project-based curriculum system for construction engineering technology specialty, Guangxi Education, (3), 64-66.

Jiang, X. Y. (2012). Research and Practice of " $2+1$ combination of work and learning-project oriented" talent training model for architectural engineering specialty. Journal of Chongqing Electric Power College, (12), 28-31.

Zhang, X. M. (2013). Investigation on the third-party teaching quality evaluation of construction engineering specialty. Journal of Shaoxing University of Arts and Sciences, (7), 97-100. http://dx.doi.org/10.16169/j.issn.1008-293x.k.2013.02.008

Peng, D. H., \& Xu, M. B. (2012). Exploration and construction of entrepreneurship education model for civil engineering majors. University Education, (8), 35-37. http://dx.doi.org/10.14018/j.cnki.cn131085/n.2018.20.109. 